\title{
Strain variations in some reproductive and production traits of purebred normal feather and naked neck FUNAAB Alpha chicken
}

Oleforuh-Okoleh, V. U., Emeka, O. C., Obianwuna, E. U. and Nnam, B. S. Department of Animal Science, Faculty of Agriculture, Rivers State University, Nkpolu-Oroworukwo, P M. B. 5080, Port Harcourt, Nigeria.

Abstract

This study was conducted to investigate reproductive and production traits in purebred normal feather and naked neck strains of FUNAAB alpha chicken (FAC) breed. Forty-five weeks old birds comprising 70 hens and 13 cocks per strain selected from random-bred populations of each strain were purebred and used to study strain variations in fertility and embryonic mortality. Their progenies were compared for juvenile growth performance (dayold to 12 weeks of age), as well as short term egg production traits (from first lay to 280 days of age). Analysis of data using multivariate analysis with strain and hatch set as fixed factors revealed that though fertility was $6.75 \%$ higher in the naked neck strain, high incidence of embryonic mortality (41.79\%) especially during the first and last 7 days of incubation resulted in poor hatchability $(P<0.05)$. Though the normal feather chicks weighed $8.92 \%$ heavier than the naked neck at day-old, those from the naked neck had generally better feed conversion ratio which translated to $8.55 \%$ heavier weight for them at 12 weeks of age $(P<0.05)$. Generally, the naked neck strain was also superior $(P<0.05)$ to the normal feather strain wing length, chest girth and leg length. Results on laying traits revealed that the normal feather hens performed better than the naked neck hens. They became sexually matured 1.87 weeks earlier than the naked neck hens, had a better feed conversion ratio of 2.25 and $3.70 \%$ higher rate of egg production at 280 days of age. Egg production was at its peak at 25-28 weeks of age and declined from 37-40 weeks of age in both strains. Our observation suggests that though possession of naked neck gene appeared to increase embryonic mortality, both strains can successfully be incorporated in breeding plans for further genetic improvement and development of egg lines (using the normal feather strain) and meat lines (using the naked neck).

Keywords: egg production, fertility, growth, hatchability, naked neck, normal feather, FUNAAB Alpha chicken

\section{Des Variations fibrille dans certains traits reproducteurs et de production de plumes $\underset{\infty}{\infty}$ normales de race pure et de poulet FUNAAB Alpha cou nu}

\section{Résumé}

Cette étude a été menée pour étudier les traits reproducteurs et de production de la race normale de race pure et du cou nu de la race de poulet alpha FUNAAB (le 'FAC'). Les oiseaux de quarante-cinq semaines comprenant 70 poules et 13 coqs sélectionnés parmi les populations élevées au hasard de chaque souche étaient de race pure et utilisés pour étudier les variations de la fertilité et de la mortalité embryonnaire. Leurs descendances ont été comparées pour la performance de croissance juvénile (de jour à 12 semaines d'âge), aussi bien que les traits à court terme de production d'oeuf (du premier lä̈g à 280 jours d'âge). L'analyse des données utilisant l'analyse multivariée avec la souche et l'ensemble d'écoutille comme facteurs fixes a indiqué que bien que la fertilité ait été $6.75 \%$ plus élevée dans la 


\section{Reproductive and production traits of purebred FUNAAB Alpha chicken}

souche nue de cou, l'incidence élevée de mortalité embryonnaire (41.79\%) particulièrement au cours des 7 premiers et derniers jours d'incubation a entraîné une mauvaise éclosion $(P<0,05)$. Bien que les poussins à plumes normales pesaient $8,92 \%$ plus lourd que le cou nu à l'âge d'un jour, ceux du cou nu avaient généralement une meilleure ration de conversion des aliments, ce qui se traduit par un poids $8,55 \%$ plus lourd pour eux à l'âge de 12 semaines $(P<0,05)$. En général, la tension nue de cou était également supérieure $(P<0.05)$ à la longueur normale d'aile de contrainte de plume, à la circonférence de coffre et à la longueur de jambe. Les résultats sur les traits de ponte ont révélé que les poules à plumes normales ont obtenu de meilleurs résultats que les poules nues au cou. Ils sont devenus sexuellement mûris 1,87 semaines plus tôt que les poules cou nu, avait un meilleur ratio de conversion des aliments pour animaux de 2,25 et 3,70\% plus élevé taux de production d'oufs à 280 jours d'âge. La production d'eufs était à son apogée à l'âge de 25-28 semaines et a diminué de 3740 semaines d'âge dans les deux souches. Notre observation suggère que bien que la possession du gène nu de cou semble augmenter la mortalité embryonnaire, les deux souches peuvent être avec succès incorporées dans les plans de reproduction pour davantage d'amélioration génétique et de développement des lignes d'oeuf (utilisant la souche normale de plume) et des lignes de viande (utilisant le cou nu).

Mots-clés: production d'œufs, fertilité, croissance, éclosion, cou nu, plume normale, poulet ALPHAFUNAAB

\section{Introduction}

Sustenance of the poultry industry is dependent on steady supply of high quality eggs and day-old chicks. Breeder factors such as strain/variety have been reported to influence fertility of eggs and embryonic mortality (Yassin et al., 2008), as well as growth (Sharifi et al., 2010) and egg production traits (Iraqi et al., 2007). These traits are critical in creation, multiplication and sustenance of high-performance lines for meat and egg type chickens. Globally, some of the breeding techniques applied in the expansion of the output of the poultry industry have resulted in genetic erosion by limiting the number of breeds/strains employed in production of commercial lines (Kejela, 2020), and vastly at the detriment of indigenous breeds. Genetic $\mathrm{x}$ environmental interaction tends to cause these commercial lines to perform below their optimum genetic potential in the tropics; being poorly adapted to its unfavourable economic, climatic, nutrition and disease environments (Horst, 1989). Consequently, majority of the poultry farmers, especially smallholders, experience high mortality and low productivity. Creation of high-performance lines and breeds for meat and egg production in Nigeria through development of sustainable breeds using the available indigenous chicken breeds/varieties would in the long run proffer solutions to these problems. To this extent, the FUNAAB Alpha chicken (FAC), a dual purpose chicken breed, was developed at Federal University of Agriculture, Abeokuta, Nigeria (NACGRAB, FMST 2018). Studies by African Chicken Genetic Gain (ACGG) Nigeria on small householder farmers revealed that the FAC was among the most preferred improved tropically adapted breeds (Bamidele et al., 2019; Yakubu et al., 2020). An important adaptive gene which was not compromised in developing the FAC is the autosomal naked neck gene $(\mathrm{Na})$. Birds with this mutant gene have a characteristic reduction of plumage mostly around the neck region (Mou et al., 2011). The $N a$ gene has been reported to be notable in conferring a better thermoregulatory tendency and efficiency in chickens reared in the tropics, or under 


\section{Oleforuh-Okoleh, Emeka, Obianwuna and Nnam}

controlled exposure to high ambient temperatures (Fathi et al., 2013). In Nigeria, the naked neck chickens appear to be going extinct and are rarely used in commercial poultry production. Relevance of incorporation of adaptability genes in breeding plans towards genetic improvement of Nigerian indigenous chickens was elucidated by Ibe (1992). Conservation and diversification of the chicken genome necessitates that the performance of all available genetic resource be assessed. This study, therefore, aimed at comparing fertility, embryonic mortality, growth, and laying traits of purebred normal feather and naked neck FAC.

\section{Materials and methods Studylocation}

This study was conducted at the Teaching and Research Farm of Rivers State University, Port Harcourt. Port Harcourt is located in the tropical wet climatic region, with mean annual temperature of $31^{\circ} \mathrm{C}$, annual rainfall of $2294 \mathrm{~mm}$, relative humidity of $71.0 \%$ and mean daylight of 12.1 hours (weather.nga.com).

\section{Stock, management and traits measured}

Forty-five weeks old birds comprising 140 hens and 26 cocks were selected from a base population of normal feather and naked neck strains (70 hens and 13 cocks per strain) of FUNAAB Alpha chicken (FAC) breed maintained at the Poultry Breeding Unit, Department of Animal Science, Rivers State University, Port Harcourt. These were bred to produce the progenies used for this study. Cocks from the two strains were assessed for semen quality traits, which included semen colour and viscosity, semen volume and concentration, sperm motility, morphology and proportion of live sperm. Those that scored $>75 \%$ on semen viability were selected and used as sires. Selection of breeding hens was based on use of total index score for selection criterion traits (body weight at first lay, egg number and egg weight) as postulated by Oleforuh-Okoleh (2013). The selected cocks and hens were transferred from floor pens to individual cages in a 3-tier battery cage and placed on $120 \mathrm{~g}$ /day breeders' diet consisting of $16.5 \%$ crude protein, $7.0 \%$ Crude fibre, and $2500 \mathrm{kcal} / \mathrm{kg}$ with potable water supplied ad libitum. Pure breeding was carried out by inseminating hens with fresh non-extended semen milked (using abdominal massage) from the cocks of same strain. Insemination was done using a micropipette and tips with semen volume dose ranging from $0.4-0.5 \mu \mathrm{l}$. A mating ratio of 1 cock:5hens was adopted to reduce possible incidence of inbreeding due to the small population size. Insemination was done weekly for two weeks prior to collection of eggs for incubation. Each hen was thereafter inseminated weekly for 3 consecutive weeks to obtain eggs for the 4 hatch (weekly) sets used for the study. For each hatch set, eggs were collected, pedigreed, sorted (to remove peewee, cracked and abnormal ones) and weighed daily, stored in an air-conditioned room (18$20^{\circ} \mathrm{C}$ ) and incubated within 5 days of collection. Candling was done during the incubation, on the $7^{\text {th }}, 14^{\text {th }}$ and $18^{\text {th }}$ day to determine fertility and embryonic mortality. On the $22^{\text {nd }}$ day newly hatched chicks were removed from the incubator, while unhatched eggs were broken to ascertain the status of the germs. Dead germs at day 7, 14 and 18 of incubation were identified as DG1, DG2 and DG3 respectively. Fully matured embryos which did not pip or hatch after pipping were classified as dead in shell (DG4). Fertility, hatchability (based on fertile eggs) and embryonic mortality were calculated using the following formula:

Fertility $\%=\{($ Number of fertile eggs $\times 100)$ /Number of eggs sets $\}$

Hatchability $\%=\{$ (Number of hatched chicks x 100 / Number of fertile eggs $\}$ 


\section{Reproductive and production traits of purebred FUNAAB Alpha chicken}

Dead Germs $(\mathrm{DG}) \%=\{$ Number of dead germs $x 100 /$ Number of fertile eggs $\}$

Six hundred and fifty-four healthy day-old chicks hatched from the two strains (389 normal feathered and 265 naked necked) were wing banded according to their pedigree, weighed and brooded in separate replicate deep litter pens using a stocking density of 15 birds $\mathrm{m}^{-1}$, with maximum of 30 birds per replicate. The chicks were fed commercial chicks mash $(21 \% \mathrm{CP}$ and 3000 $\mathrm{kcal} / \mathrm{kg}$ ) from day-old to 6 weeks of age, and growers mash (16\% CP and $2900 \mathrm{kcal} / \mathrm{kg}$ ) from $6-12$ weeks of age. Weekly body weight (BW) and feed intake (FI) was measured and the data obtained on feed intake (FI) and body weight gain (BWG) used to estimate feed conversion ratio (FCR). Measurement of body morphometric traits was done monthly from day-old to 12 weeks of age using 20 birds per replicate. Traits considered as measures of growth included body weight $\mathrm{BW}$, body length $\mathrm{BL}$, chest girth $\mathrm{CG}$, wing length WL, leg length LL, shank length SL, and shank circumference SC. All body measurements except body weight (got using an electronic weighing scale; $0.01 \mathrm{~g}$ sensitivity) were obtained using a flexible cloth measuring tape according to the descriptions in Guèye et al. (1998). At 17 weeks of age, 150 pullets (75 per strain) were randomly selected from the progeny population and transferred to a three-tier battery cage where they were placed in individual cells. Each bird received $100 \mathrm{~g}$ of layers' mash $(16.5 \% \mathrm{CP}$ and $2500 \mathrm{kcal} / \mathrm{kg})$ daily. Laying traits monitored included age, body weight and egg weight at sexual maturity, monthly egg weight and egg number from first lay to 280 days of age. Records from these were used to estimate rate of egg production expressed as the ratio of total number of egg laid from first lay to 280 days of age to number of birds alive within these period ((hen day egg production HDEP), egg mass (the product of \%HDEP and egg weight) and feed conversion ratio (estimated as ratio of feed consumed to egg mass).

\section{Statistical analysis}

Statistical analyses were computed using the multivariate analysis of general linear model program available in IBM SPSS (IBM SPSS, 2015) to ascertain the strain and batch/hatch effect on fertility, hatchability and embryonic mortality, growth and laying traits using the experimental model: $\mathrm{X}_{\mathrm{i} \mathrm{k}}=\mu+\mathrm{S}_{\mathrm{i}}+\mathrm{H}_{\mathrm{j}}+$ $S H_{i j}+\mathrm{E}_{i \mathrm{ik}}$, where, $\mu=$ observed mean; $\mathrm{S}=$ strain type; $\mathrm{H}=$ hatch group; $S H=$ interaction of strain $\mathrm{x}$ hatch; $\mathrm{E}=$ random error. However, because there was no significant hatch or strain $\mathrm{x}$ hatch interaction effect on all traits studied, therefore their effects were not included in the result presented. Separation of significant means $(\mathrm{P}<0.05)$ was done using Turkey (IBM SPSS, 2015).

\section{Results and discussion Fertility and hatchability}

Mean values of fertility, hatchability and embryonic mortality of the strains studied are shown in Table 1. Analysis of variance indicated significant strain variations $(p<0.05)$ in these traits. Though the naked neck strain exhibited superior fertility $(6.75 \%)$ over the normal feathered, its hatchability was observed to be lower (23.85\%). Our observation was contrary to Peters et al. (2008) which reported significantly better fertility and hatchability in the normal feather compared to the naked neck chicken, but it affirms the findings of Bobbo et al. (2013) and Sidadolog et al. (2015). 
Table 1: Fertility and hatchability $(M e a n \pm S E)$ of the normal feather and naked neck FAC ${ }^{1}$

\begin{tabular}{lll}
\hline Trait & Normal Feather & Naked neck \\
\hline Fertility (\%) & $77.59 \pm 2.06^{\mathrm{a}}$ & $83.21 \pm 2.80^{\mathrm{b}}$ \\
Hatchability(\%) & $75.02 \pm 4.37^{\mathrm{a}}$ & $57.13 \pm 1.73^{\mathrm{b}}$ \\
DG1 (\%) & $7.97 \pm 2.40^{\mathrm{b}}$ & $13.19 \pm 2.15^{\mathrm{a}}$ \\
DG2 (\%) & $6.98 \pm 0.68$ & $8.43 \pm 1.50$ \\
DG3 (\%) & $6.18 \pm 1.23^{\mathrm{b}}$ & $11.81 \pm 2.30^{\mathrm{a}}$ \\
DG4 (\%) & $3.85 \pm 1.40^{\mathrm{b}}$ & $9.49 \pm 0.81^{\mathrm{a}}$ \\
\hline
\end{tabular}

${ }_{\mathrm{a}, \mathrm{b}}$ Means on the same row with no common superscripts differ significantly $(P<0.05)$.

${ }^{1}$ FAC: FUNAAB Alpha Chicken; DG1: Dead germs between 1-7 days of incubation; DG2: Dead germs between $7-14$ days of incubation; DG3: Dead germs between $15-18$ days of incubation; DG4: Dead germ 19 -21 days (fully matured embryos that did not pip or hatch after pipping)

Poor hatchability seen is as a result of high incidence $(\mathrm{P}<0.05)$ of embryonic mortality, about $42.87 \%$ in the naked neck FAC (especially at DG1, DG3 and DG4) compared to $24.98 \%$ in the normal feather. Several studies indicate that genetic composition of the embryo tends to influence its viability. Benedict et al. (1932) and Hutt and Sturkie (1938) noted that possession of the naked neck gene, could be detrimental to the viability of chicken embryos, with much of the mortality occurring when embryos are homozygous for this incomplete dominant autosomal mutant and sex-linked gene (Adeleke et al., 2012). Previous studies indicated that heterozygosity seem to confer more viability advantage to embryos bearing the naked neck gene than homozygote condition (Setianto et al., 2009; Oshinbowale, 2017). Though Merat (1990) postulated that possession of fewer feathers in the neck region could result in embryonic mortality associated with malposition of the embryo prior to hatching, Sharifi et al. (2006) found no significant variations due to genotype on malposition of late dead embryos. Poor hatchability in the naked neck birds has also been traced to metabolic disorders in the maternal physiology. Such disorders induced by reduction in feather leads to disturbances in thermo-regulation which increases plasma and hormonal activity influencing the deposition of substances needed for normal embryonic development (Landauer, 1961; Decuypere et al., 1993). Embryonic mortality is of great economic concern to the poultry industry. Two peak periods of embryonic mortality were observed from our findings, irrespective of the strain type. The peaks occurred during the first $(32.09 \%)$ and last $(46.20 \%)$ seven days of incubation. Abnormal chromosome complements have been implicated in the occurrence of early embryonic mortalities (Thorne et al., 1991). Higher embryonic mortality observed within the last seven days of incubation affirms the findings of Peñuela and Hernandez (2018) who in a study to characterize occurrence of embryonic mortality in Ross broilers also found peak mortality within the last days of incubation. The last stage of embryonic development has been described as the most vital stage (Jassim et al. 1996). Reduced embryonic survivability at this stage is linked to three major physiological changes which occur between the $16^{\text {th }}-20^{\text {th }}$ day of incubation. These physiological changes relate to modification in the diet of the embryo from the $17^{\text {th }}$ day when the yolk is utilized and absorbed as the main source of nutrition; subsequent passing of unabsorbed yolk into the body cavity; and change in the respiratory system from using the allantois as the system of respiration to pulmonary respiration (Payne, 1919). 
Growth performance and body morphometric traits

Mean BW, BWG, FI, FCR and mortality from day old to 12 weeks of age of the two strains studied are presented in Table 2 . Significant variations $(\mathrm{P}<0.05)$ were found between the strains in BW, BWG, FCR and mortality. Several studies have indicated that possession of naked neck gene conferred heavier body weights on naked neck chicks due to better feed utilization efficiency (Gunn, 2008; Sharifi et al, 2010).
This has been attributed to improved ability for dissipation of heat and diversion of protein from feather production to development of muscle tissues in the naked neck strains (Patra, 2002). Post-hatch mortality was $1.60 \%$ more $(\mathrm{P}<0.05)$ in the naked neck strain, especially between dayold and 4 weeks of age, than the normal feather FAC. Though the normal feather chicks were heavier $(8.92 \%)$ at day-old, those from the naked neck had better FCR which translated to $8.55 \%$ heavier weight at 12 weeks of age $(\mathrm{p}<0.05)$.

Table 2 Comparison of growth performance between normal feather and naked neck FUNAAB Alpha chicken

\begin{tabular}{llll}
\hline Trait & \multicolumn{2}{c}{$\begin{array}{c}\text { Strain } \\
\text { Normal feather }\end{array}$} & p-value \\
\hline Body weight, $\mathbf{g}$ & & & \\
Day-old & $39.01 \pm 0.50^{\mathrm{a}}$ & $35.53 \pm 0.34^{\mathrm{b}}$ & 0.000 \\
4 weeks & $143.04 \pm 6.10$ & $150.36 \pm 2.30$ & 0.074 \\
8 weeks & $512.73 \pm 12.47$ & $550.75 \pm 18.85$ & 0.059 \\
12 weeks & $1178.42 \pm 30.50^{\mathrm{b}}$ & $1288.55 \pm 25.11^{\mathrm{a}}$ & 0.001 \\
Body weight gain, $\mathbf{g}$ & & & \\
Day-old -4 weeks & $104.02 \pm 2.11^{\mathrm{b}}$ & $114.83 \pm 2.28^{\mathrm{a}}$ & 0.001 \\
$4-8$ weeks & $369.69 \pm 5.74^{\mathrm{b}}$ & $400.39 \pm 9.35^{\mathrm{a}}$ & 0.005 \\
$8-12$ weeks & $665.68 \pm 15.12^{\mathrm{b}}$ & $737.81 \pm 14.46^{\mathrm{b}}$ & 0.001 \\
$0-12$ weeks & $1139.42 \pm 14.63^{\mathrm{b}}$ & $1253.02 \pm 10.07^{\mathrm{a}}$ & 0.000 \\
Total feed intake, g & $2352.94 \pm 3.69$ & $2351.95 \pm 4.58$ & 0.633 \\
Feed conversion ratio & $2.06 \pm 0.01^{\mathrm{a}}$ & $1.88 \pm 0.03^{\mathrm{b}}$ & 0.000 \\
Mortality, \% & & & \\
$0-4$ weeks & $4.37 \pm 0.41^{\mathrm{b}}$ & $5.28 \pm 0.45^{\mathrm{a}}$ & 0.043 \\
$4-8$ weeks & $1.61 \pm 0.24$ & $1.19 \pm 0.22$ & 0.179 \\
$8-12$ weeks & $1.64 \pm 0.06^{\mathrm{b}}$ & $2.82 \pm 0.13^{\mathrm{a}}$ & 0.000 \\
$0-12$ weeks & $7.45 \pm 0.29^{\mathrm{b}}$ & $9.05 \pm 0.13^{\mathrm{a}}$ & 0.010 \\
\hline a,b Means on the same row with no common superscripts differ significantly $(P<0.05)$.
\end{tabular}

From Table 3, it is apparent that although the normal feathered strain had higher mean values $(\mathrm{P}<0.05)$ for $\mathrm{BL}, \mathrm{WL}, \mathrm{SL}$ and $\mathrm{SC}$ at day-old, the naked neck strain exhibited faster growth such that at 12 weeks of age they had better performance $(p<0.05)$ in BL, CG, WL, and LL. The present findings confirm previously reported results of Yalcin et al. (1997) and Islam and Nishbori (2009) indicating that the possession of the naked neck gene improves growth rate. The larger CG and longer LL observed in naked neck strain at 4 and 12 weeks of age depicts development of more muscle at the pectoral and hind limb regions. Significantly heavier chest and leg weight in naked neck chickens at different ages have been recorded (Hagan et al., 2011; Adomako et al., 2014). Our findings, thus, affirms the submissions of Singh et al. (1998) and Yunis and Cahaner (1999) on the relevance of the naked neck gene in development and genetic improvement of fast-growing chickens in the tropics. 
Oleforuh-Okoleh, Emeka, Obianwuna and Nnam

Table 3 Body measurements (Mean \pm SE) of normal feather and naked neck FUNAAB Alpha chicken at different ages

\begin{tabular}{llllllll}
\hline Age & Strain & BL & CG & WL & LL & SL & SC \\
\hline Day-old & NF & $13.29 \pm 0.08^{\mathrm{a}}$ & $8.92 \pm 0.06$ & $5.46 \pm 0.03^{\mathrm{a}}$ & $5.47 \pm 0.04$ & $2.71 \pm 0.02^{\mathrm{a}}$ & $1.55 \pm 0.01^{\mathrm{a}}$ \\
& NN & $12.96 \pm 0.09^{\mathrm{b}}$ & $9.06 \pm 0.08$ & $4.94 \pm 0.04^{\mathrm{b}}$ & $5.39 \pm 0.06$ & $2.56 \pm 0.02^{\mathrm{b}}$ & $1.50 \pm 0.01^{\mathrm{b}}$ \\
P-value & & 0.010 & 0.205 & 0.000 & 0.245 & 0.000 & 0.011 \\
4 weeks & $\mathrm{NF}$ & $19.64 \pm 0.09$ & $12.84 \pm 0.07^{\mathrm{b}}$ & $11.32 \pm 0.19^{\mathrm{b}}$ & $8.54 \pm 0.04^{\mathrm{b}}$ & $3.81 \pm 0.03$ & $2.47 \pm 0.05$ \\
& $\mathrm{NN}$ & $19.99 \pm 0.09$ & $13.20 \pm 0.06^{\mathrm{a}}$ & $13.45 \pm 0.34^{\mathrm{a}}$ & $8.67 \pm 0.04^{\mathrm{a}}$ & $3.76 \pm 0.03$ & $2.56 \pm 0.05$ \\
P-value & & 0.073 & 0.000 & 0.000 & 0.023 & 0.505 & 0.109 \\
8 weeks & $\mathrm{NF}$ & $30.06 \pm 0.24$ & $18.85 \pm 0.11^{\mathrm{b}}$ & $14.38 \pm 0.07^{\mathrm{b}}$ & $14.47 \pm 0.06^{\mathrm{b}}$ & $6.45 \pm 0.02$ & $3.71 \pm 0.08$ \\
& $\mathrm{NN}$ & $29.26 \pm 0.42$ & $19.67 \pm 0.07^{\mathrm{a}}$ & $15.04 \pm 0.07^{\mathrm{a}}$ & $16.29 \pm 0.11^{\mathrm{a}}$ & $6.51 \pm 0.03$ & $3.79 \pm 0.06$ \\
P-value & & 0.101 & 0.000 & 0.000 & 0.000 & 0.731 & 0.084 \\
12 weeks & $\mathrm{NF}$ & $36.60 \pm 0.32^{\mathrm{b}}$ & $26.79 \pm 0.28^{\mathrm{b}}$ & $19.67 \pm 0.04^{\mathrm{b}}$ & $17.15 \pm 0.17^{\mathrm{b}}$ & $8.40 \pm 0.08$ & $4.39 \pm 0.02$ \\
& $\mathrm{NN}$ & $39.34 \pm 0.23^{\mathrm{a}}$ & $28.19 \pm 0.09^{\mathrm{a}}$ & $22.74 \pm 0.37^{\mathrm{a}}$ & $18.47 \pm 0.09^{\mathrm{a}}$ & $8.89 \pm 0.03$ & $4.44 \pm 0.01$ \\
P-value & & 0.000 & 0.000 & 0.000 & 0.000 & 0.731 & 0.275 \\
\hline
\end{tabular}

${ }^{a b}$ Means on the same column (for each week of study) with no common superscripts differ significantly

BL - Body length; CG - Chest girth; WL - Wing length; LL - Leg length; SL - Shank length; SC - Shank circumference

\section{Laying traits}

The beginning of sexual maturity is of utmost economic importance in poultry production since it plays a critical role in measuring the fecundity as well as economic gains of the flock. Means and standard errors for overall laying traits are presented in Table 4 for the normal feather and naked neck FAC studied. The normal feather hens came into lay 1.87 weeks earlier $(p<0.05)$ than the naked neck hens and had $6.38 \%$ and $7.32 \%$ lighter $(\mathrm{P}<0.05)$ body weight and egg weight respectively at first lay.

Table 4: Overall laying performance $(\mathrm{Mean} \pm \mathrm{SE})$ of the two $\mathrm{FAC}^{1}$ strains studied

\begin{tabular}{|c|c|c|}
\hline Traits & Normal feather (75) & Naked neck (75) \\
\hline Age at first lay (weeks) & $23.73 \pm 0.20^{\mathrm{b}}$ & $25.60 \pm 0.16^{\mathrm{a}}$ \\
\hline Body weight at first lay (g) & $1384.55 \pm 6.99^{b}$ & $1478.90 \pm 8.80^{\mathrm{a}}$ \\
\hline Weight First Egg (g) & $35.57 \pm 0.45^{\mathrm{b}}$ & $38.36 \pm 0.31^{\mathrm{a}}$ \\
\hline $\operatorname{HDEP}(\%)$ & $69.99 \pm 0.73^{\mathrm{a}}$ & $63.73 \pm 0.96^{\mathrm{b}}$ \\
\hline Egg number/week & $4.88 \pm 0.02^{\mathrm{a}}$ & $4.42 \pm 0.02^{\mathrm{b}}$ \\
\hline Egg Weight $_{280 \text { days }}(\mathrm{g})$ & $51.67 \pm 0.16$ & $51.63 \pm 0.09$ \\
\hline Egg mass (g/day) & $36.47 \pm 0.11^{\mathrm{a}}$ & $33.26 \pm 0.06^{\mathrm{a}}$ \\
\hline Feed conversion ratio & $2.25 \pm 0.01^{\mathrm{b}}$ & $2.53 \pm 0.01^{\mathrm{a}}$ \\
\hline
\end{tabular}

${ }^{\mathrm{ab}}$ Means on the same row with no common superscripts differ significantly $(P<0.05)$.

Our finding further revealed that though the normal feather strain laid 11 eggs more $(\mathrm{p}<0.01)$ than the naked neck within the period of study, both had similar average egg weight at 280 days of age. The mean age, body weight and egg weight at first lay obtained from the birds studied is within the range reported by Wheto et al. (2017) for FUNAAB Alpha chickens. The laying performance of the normal feather and the naked neck strain in the present study confirms the report of Adebambo (2015) which showed that the normal feather and the naked neck at maturity had similar mean egg weight ranging from $52.75-53.15 \mathrm{~g}$.

Table 5 shows the result on mean monthly egg production within the short-term laying period studied. There were significant $(\mathrm{P}<0.05)$ strain variations in egg weight across the different monthly period of lay except at 37-40 weeks of age. Eggs from the naked neck strain were heavier than those 


\section{Reproductive and production traits of purebred FUNAAB Alpha chicken}

from the normal feather between 21-24 and 25-32 weeks of age. This could be traced to the age and body weight at first lay as indicated in Table 4. Highly significant
$(\mathrm{P}<0.01)$ strong and positive phenotypic and genetic associations have been found between these traits in chickens (OleforuhOkoleh, 2013).

Table 5: Short term egg laying performance (from first lay to 280 days of age)

\begin{tabular}{lllllll}
\hline Age(weeks) & \multicolumn{2}{c}{ Egg weight, g } & \multicolumn{2}{c}{ Egg number, eggs } & \multicolumn{2}{c}{ HDEP, \% } \\
& NF & NN & NF & NN & NF & NN \\
\hline $21-24$ & $45.81^{\text {by }}$ & $47.22^{\text {az }}$ & $10.18^{\text {bz }}$ & $8.10^{\text {bz }}$ & $36.35^{\text {az }}$ & $28.93^{\text {bz }}$ \\
$25-28$ & $45.83^{\text {by }}$ & $51.41^{\text {ay }}$ & $22.98^{\text {bw }}$ & $20.50^{\text {bx }}$ & $82.07^{\text {aw }}$ & $73.21^{\text {bx }}$ \\
$29-32$ & $52.32^{\text {ax }}$ & $51.78^{\text {by }}$ & $21.73^{\text {bx }}$ & $20.57^{\text {bx }}$ & $77.61^{\text {ax }}$ & $73.46^{\text {bx }}$ \\
$33-36$ & $52.69^{\text {ax }}$ & $51.93^{\text {by }}$ & $21.59^{\text {bx }}$ & $20.71^{\text {bx }}$ & $77.10^{\text {ax }}$ & $73.96^{\text {bx }}$ \\
$37-40$ & $52.71^{\text {x }}$ & $52.80^{\text {x }}$ & $21.05^{\text {ay }}$ & $18.43^{\text {by }}$ & $75.18^{\text {ay }}$ & $65.82^{\text {by }}$ \\
\hline
\end{tabular}

${ }^{a b}$ Means on the same row (for each trait) with no common superscripts differ significantly

${ }^{x y}$ Means on the same column (for each trait) with no common superscripts differ significantly

HDEP - Hen day egg production

Increased egg number by the normal feather throughout the five months period of study improved their monthly HDEP $(\mathrm{P}<0.05)$ above those of the naked neck. Peak egg production was achieved by both strains at 25-28 weeks of age with the least rate of production observed at 37-40 weeks of age. Sharp drop in egg production between 25-28 weeks of age and 29-32 weeks of age (up to $5.44 \%$ ) was observed in the normal feather, whereas the naked neck had a drop after the 36 weeks of age. Earlier studies by Emeka et al. (2019) on FUNAAB Alpha chickens had indicated a similar trend. Adetayo and Babafunso (2001) and Dana et al. (2011) observed rapid rise in rate of egg production from sexual maturity to about second to fourth month of lay before declining.

\section{Conclusion}

Possession of the naked neck gene reduced embryonic viability but improved juvenile growth traits. Superiority in growth performance and body morphometric traits such as larger chest girth and longer limbs in the naked neck strain suggests that its genome could be harnessed in genetic improvement and development of meat lines in Nigeria. The normal feather strain which showed more advantage in laying traits, on the other hand, could be more beneficial as parent stock for layer line production.

\section{Acknowledgment}

The authors are very grateful to the Teaching and Research Farm, Faculty of Agriculture, Rivers State University, Port Harcourt, Nigeria for allowing them to use its facilities.

\section{References}

Adebambo, O.A. 2015. From Pearl Project to ACGG in Nigeria. Paper presented at the first $A C C G$ Nigeria Innovation Platform meeting, Ibadan, Nigeria, 20-22 $\begin{array}{lllll}\mathrm{J} & \mathrm{y} & \mathrm{y} & 0 & 1\end{array}$. https://cgspace.cgiar.org/bitstrea $\mathrm{m} /$ handle/10568/72670/acggpearl nigeriajul $\square 2015$

Adeleke, M. A., Peters, S. O., Ozoje, M. O., Ikeobi, C. O.N., Bamgbose, A. M., Adebambo, O.A. 2012. Effect of crossbreeding on fertility, hatchability and embryonic mortality of Nigerian local chickens. Tropical Animal Health and Production 44: 505-510. 
doi:10.1007/s11250-011-9926-X.

Adetayo, A. S. and Babafunso, S. E. 2001.

Comparisons of the performance of Nigerian indigenous chickens from three agro-ecological zones. Livestock research for rural development. Volume 13, Article\#15. Retrieved September, $15, \quad 2020, \quad$ f $\mathrm{r}$ o m http://www.lrrd.org/lrrd13/2/aded $132 \mathrm{htm}$.

Adomoko, K., Olympio, O. S., Hagan, J. K. and Hamidu, J. A. 2014. Growth performance of crossbred naked neck and normal feathered laying hens kept in tropical villages. British Poultry Science 55:701-708.

Bamidele, O., Sonaiya, E. B., Adebambo, O. A., and Dessie, T. 2019. Onstation performance evaluation of improved tropically adapted chicken breeds for smallholder poultry production systems in Nigeria." Tropical Animal Health a nd Production. doi.org/10.1007/s11250-01902158-9.

Benedict, F. G., Landauer, W. and Fox, E. L. 1932. The physiology of normal and frizzle fowl with special reference to the basal metabolism. Storrs Agricultural Experiment Station Bulletin 177.

Bobbo, A. G., Yahaya, M. S. and Baba, S. S. 2013. Comparative assessment of fertility and hatchability of three phenotypes of local chickens in Adamawa State. Journal of Agriculture and Veterinary Science, (2): 22-28.

Dana, N., Waaijvander, E. H., Arendonk van, J. A. M. 2011. Genetic and phenotypic $\quad \mathrm{param}$ e $\mathrm{te} \mathrm{r}$ estimates for body weights and egg production in Horro chicken of Ethiopia. Tropical Animal Health and Production 43:21-28. DOI $10.1007 / \mathrm{s} 11250-\quad 0 \quad 10$ 9649-4

Decuypere, E., Buyse, J., Merat, P., Zoons, J. and Vloeberghs, I. 1993. Growth, Abdominal fat content, heat production and plasma hormone levels of nakedneck and control broiler chickens. Animal Production. 57:483-490. Doi: 10.3389/fgene.2015.00013.

Emeka, O. C., Oleforuh-Okoleh, V. U. and Etekpe, G. W. 2019.Egg production traits in normal feathered and naked necked Nigerian indigenous chickens. Delta Agriculturist 11:1-9.

FAO. 2014. Meat and Meat Products in Animal Production and Health. Agriculture and Consumer Protection Department, Food and Agriculture Organization. www.fao.org/ag/againfo/themes/e n/meat/background.html

Fathi, M. M., Galal, A., El-Safty, S. and Mahrous, M. 2013. Naked neck and frizzle genes for improving chickens raised under high ambient temperature: 1. Growth performance and egg production. World's Poultry Science Journal $69: 813-832$. DOI : 10.1017/S0043933913000834.

Guèye, E. F., Ndiaye, A. and Branckaert, R. D. S. 1998. Prediction of body weight on the basis of body measurement in mature indigenous chickens in Senegal. Livestock Research for Rural Development. Volume 10: Article \#28. Retrieved October 4, 2020.

Hagan, J. K., Adomako, K. and Olympio, O. S. 2011. Effects of naked-neck and frizzle genes on growth performance and carcass characteristics of crossbred cockerels. Journal of Science and 
Technology, Vol. 31, No. 3 (2011), $\begin{array}{ll}p p & 42-47 \text {. }\end{array}$ http://dx.doi.org/10.4314/just.v31i 3.5

Horst, P. 1989. Native fowls as reservoir for genomes and major genes with direct and indirect effects on adaptability and their potential for tropical oriented breeding plans. Animal Breeding Abstract 53: 93. http://data.ilri.org/portal/dataset.

Hutt, F. B. and Sturke, P. D. 1938. Genetics of the fowl. IX. Naked. A new sex linked mutation. Journal of Heredity 29:371-379. doi.org/10.1093/oxfordjournals.jh ered.a104413.

Ibe, S. N. 1992. Incorporating adaptability genes in poultry breeding programmes in Nigeria. Proceedings of the 18th World's Poultry Congress, Nagoya. Japan.

IBM SPSS. 2015.Statistics for Windows, Version 23.0. Armonk, NY: IBM Corp.

Iraqi, M. M., Afifi, E. A., El-Labban, A. M. and Afram, M. 2007. Heterotic and genetic components in $4 \times 4$ diallel mating experiment for egg production traits in chickens. 4th World $P$ o $\quad u \quad l \quad t \quad r y$ Conference 27 - 30 March 2007, Sharm El-Sheikh, Egypt.

Islam, M. A. and Nishibori, M. 2009. Indigenous naked neck chicken: a valuable genetic resource for Bangladesh. World's Poultry Science Journal 65:125-138.

Jassim, E. W., Grossman, M., Koops, W. J. and Luykx, R. A. J. 1996. Multiphasic analys is of embryonic mortality in chickens. Poultry Science. 75:464-471. doi.org/10.3382/ps.0750464

Kejela, Y. 2020. Introduction of the exotic breeds and cross breeding of local chicken in Ethiopia and solution to genetic erosion: A review. African Journal of Biotechnology 19(2): $92-98$ d o $i$ : 10.5897/AJB2019.16748

Landauer, W. 1961. Hatchability of chicken eggs as influenced by environment and heredity. The University of Connecticut Storrs.37-48. do $i$ : 10.1080/09712119.1998.9706671

Merat, P. 1990. Pleiotropic and associated effects of major genes. In: Poultry Breeding and Genetics. Edited by: R. D. Crawford. 429-467. Elsevier Scientific Publishers, Amsterdam, The Netherlands.

Mou, C., Pitel, F., Gourichon, D., Vignoles, F., Tzika, A., Tato, P., Yu, L., Burt, D. W., Bed'hom, B., Tixier-Boichard, M., Painter, K. J. and Headon, D. J. 2011. Cryptic patterning of avian skin confers a developmental facility for loss of neck feathering. PLoSBio 19(3): e $\begin{array}{llllllll}1 & 0 & 0 & 1 & 0 & 2 & 8\end{array}$. doi:10.1371/journal.pbio. 1001028

NACGRAB, FMST. 2018. The national register for chicken of national committee for the naming, registration and release of crop varieties and livestock breeds. National Centre for Genetic Resources and Biotechnology, Federal Ministry of Science and Technology 3-4.

Oleforuh-Okoleh, V. U. 2013. Genetic gains from within-breed selection for egg production traits in a Nigerian local chicken. Journal of Agricultural and Biological Sciences, 8: 788-792.

Osinbowale, D. A. 2017. Molecular identification of naked neck genotypes and comparison of their reproductive performances with frizzle and normal feathered chicken genotypes. M. Agric. 
Dissertation, Department of Animal Breeding and Genetics, Federal University of Agriculture, Abeokuta, Nigeria. 149pp.

Patra, B. N., Bais, R. K. S., Prasad, R. B. and Singh, B. P. 2002 . Performance of naked neck versus normally feathered coloured broilers for growth, carcass traits and blood biochemical parameters in tropical climate. AsianAustralas Journal of Animal Science, 15: 1776-1783. doi.org/10.5713/ajas.2002.1776.

Payne, L. F. 1919. Distribution of mortality during the period of incubation. The Journal of the American Association of Instructors and Investigators in Poultry Husbandry, 7 (2):9-12. doi.org/10.3382/ps.0060009a

Peñuela, A. S. and Hernandez, A. V. 2018. Characterization of embryonic mortality in broilers. Revista MVZ Córdoba 23:65006513. doi: 10.21897/rmvz.1245

Peters, S.O., Ilori, B.M., Ozoje, M.O., Ikeobi, C.O.N. and Adebambo, O.A. 2008. Gene segregation effects on fertility and hatchability of pure and crossbred chicken genotypes in the humid tropics. International Journal of Poultry Science 7: 954-958.

Setianto, J., Warnoto, W. and Triadi, T. 2009. Estimation of na gene frequency on native chicken population and its effect on hatchability performance. Journal of Indonesian Tropical Animal Agriculture 34:284-288.

Sharifi, A.R., Horst, P. and Simianer, H. 2010. The effect of naked neck gene and ambient temperature and their interaction on reproductive traits of heavy broiler dams. Poultry Science, 89: 1360-1371. doi:10.3382/ps.2009-00593.

Sidadolog, J. H. P., Yuwanta, T., Wihandoyo, S., Harimurti, S., Sudaryati, S., Sasongko, H. and Ariyadi, B. 2015. Analysis of reproductive potential and hatchability of naked neck and normal hens. The $6^{\text {th }}$ International Seminar on Tropical Animal Production. Integrated Approach in Developing Sustainable Tropical Animal Production. October 20-22, 2015, Yogyakarta, Indonesia. 391396.

Singh, B., Singh, B. P., Singh, S., Chaudhary, D. and Malik, C. 1998. Naked Neck: A Noble Gene for Broiler Production in Tropical Climate. Journal of Applied Animal Research, 13:1-2.

Thorne, M. H., Collins, R. K. and Sheldon, B. L. 1991.Chromosome analysis of early embryonic mortality in layer and broiler chickens, British Poultry Science, 32: 711-722.doi:10.1080/0007 166 9108417397

Wheto, M., Adenaike, A. S., Sanda, A. J., Ilori, B. M., Akano, K., Sanni., T., Olowofeso, O., Ikeobi, C. O. N. and Adebambo, O. A. 2017. Association between insulin-like growth factor-1 (IGF-1) gene polymorphism and carcass traits in improved Nigerian indigenous chickens. Nigerian Journal of Biotechnology 33: 125-130. doi.org/10.4314/v33i1.18.

Yakubu, A., Bamidele, O., Hassan, W. A., Ajayi, F. O., Ogundu, U. E., Alabi, O., Sonaiya, E. B. and Adebambo, O. A. 2020.Farmers' choice of genotypes and trait preferences in tropically adapted chickens in five agro-ecological zones in Nigeria. Tropical Animal Health and Production 52: 95-107. 
doi.org/10.1007/s 11250-01901993-0.

Yalcin, S., Testik, A., Ozkan, S., Settar , P., Celen, F. andCahaner, A. 1997. Performance of naked neck and normal broilers in hot, warm and temperate climates. Poultry Science, $76: 930-937$. doi:10.1093/ps/76.7.930.PMID:92 00226
Yassin, H., Velthuis, A. G. J., Boerjan, M., van Riel,J. and Huirne, R. B. M. 2008. Field study on broiler eggs hatchability. Poultry Science $87: 2408-2417$. doi:10.3382/ps.2007- 00515

Yunis, R. and Cahaner, A. 1999. The effects of the naked neck $(\mathrm{Na})$ and frizzle $(F)$ genes on growth and meat yield of broilers and their interactions with ambient temperatures and potential growth rate. Poultry Science 78:1347. doi.org/10.1093/ps/78.10.1347

Received: $28^{\text {th }}$ September, 2020 Accepted: $20^{\text {th }}$ January, 2021 